International Journal of

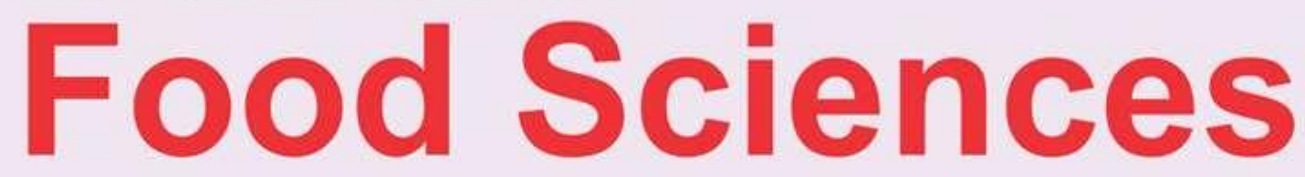

(IJF)

Comparative analyses on the chemical compostion, phytochemci mal and antioxidant properties of selected milled varieties (finger and pearl millet)

Sanusi Shamsudeen Nassarawa and Salamatu Ahmad Sulaiman 


\title{
Comparative analyses on the chemical compostion, phytochemci mal and antioxidant properties of selected milled varieties (finger and pearl millet)
}

\author{
${ }^{1 *}$ Sanusi Shamsudeen Nassarawa \\ *Lecturer, Department of Food Science and Technology, Faculty of Agriculture,Bayero \\ University Kano. P.M.B. 3011, Kano State, Nigeria \\ Corresponding Author's Email: shamsudeensunusi2015@gmail.com \\ ${ }^{2}$ Salamatu Ahmad Sulaiman \\ Lecturer, Department of Food Science and Technology, Faculty of Agriculture, Bayero \\ University Kano \\ Corresponding Author's Email: shamsudeensunusi2015@gmail.com, \\ snsanusi.fst@buk.edu.ng
}

\begin{abstract}
Purpose: Millet is a major food source in the arid and semi-arid parts of the world especially among people with low socio-economic status. It is a good source of energy, protein, minerals, dietary Fibre, fatty acid, amino acid (especially sulphur containing amino acid), phytochemicals and a good source of antioxidant.

Methods: The millet varieties were obtained from the central market in Katsina state, Nigeria. The millet varieties (finger and pearl millet) were cleaned by washing in water, de-watered, sun dried, milled into flour and stored in sealed polythene bags. Standard method were used to determine the phytochemical, atomic absorption spectrometer, amino acid profile was determined spectrometically using a gas chromatography (GC), antioxidant property was measured by determination of free radical scavenging ability (DPPH,FRAP and ABTS) and data was analyzed by one way analysis of variance (ANOVA) using SPSS (16.0) software. The result obtained from studied millet varieties showed the fatty acid profile contain more than $70 \%$ unsaturated fatty acid. Amino acid profile showed the presence of essential amino acid of nutritional importance (especially the sulphur containing amino acids).
\end{abstract}

Results: The results obtained from the studied millet varieties showed a protein content level within the range of $(10.09 \%-10.85 \%)$, fat content level between the range $(2.76 \%-4.43 \%)$, carbohydrate, fat and ash content between the range $(71.56 \%-73.18 \%),(2.23 \%-3.24 \%)$ and $(0.86 \%-1.94 \%)$ respectively. The mineral composition showed it contained mineral elements of health importance, such as; phosphorus, calcium, potassium, sodium and magnesium as well as other minor elements such as copper, manganese, zinc and iron. Phytochemical analyses showed the presence of plant chemical such as; tannin, terpenoid, alkaloid, cardiac glycoside, saponin, oxalate, phytate, flavonoids and total phenol. Antioxidant analyses showed they possess ability to serve as reducing agent hence a rich source of antioxidant of health importance.

Unique contribution to theory, practice and policy: The study revealed a high nutritional quality and possible therapeutic effect of the studied millet varieties which are locally sourced and relatively cheaper source of food for a teeming population like ours.

Keyword: Finger millet, Pearl Millet, Proximate, Mineral, Phytochemical, Antioxidant. 


\subsection{INTRODUCTION}

Nigeria as a country is faced with the problem of feeding its teeming population; therefore it is important to explore local biodiversity such as millet which is at present underutilized. In many developing countries such as Nigeria, malnutrition is an endemic dietary problem characterized by protein-energy malnutrition and micro-nutrient deficiency (WHO, 2005). The determination of the nutritional composition of these millet varieties will go a long way in providing information (nutritional data) about the selected millet varieties, which in turn will create awareness about the underlying potentials of this underutilized cereal, hence increasing utilization both industrial and household levels, hereby going a long way in achieving the core objectives of this country in feeding its teeming populace with safe and nutritious food.

Fonio millet (Setaria italic) is also known as Italian, Hungarian, German and Siberian millet (Bavec \& Bavec, 2006). The plant height varies between 1-1.5m. The inflorescence is tight, has short side branches and varies from $7.5-25 \mathrm{~cm}$ in length and $1.2-5 \mathrm{~cm}$ in diameter ((Bavec \& Bavec, 2006; Rachie, 1975; FAO, 1995). The panicle resembles the tail of a fox; the color of the grain varies from yellow to orange to red to brown and black. The weight of 1000 seeds is about $2 \mathrm{~g}$ (Bavec, 2006). Finger millet (Eleusine coracana) represents a staple food for a large segment of the population (Bavec \& Bavec, 2006). It has high nutritional value and is a good source of calcium, phytochemicals and Dietary Fibre. As the grains can be stored for a long duration without damage from pests and insects, it plays a major role during natural calamities.

The height of plants reaches from 0.4 to $1 \mathrm{~m}$ and the length of the spikes is between $3-13 \mathrm{~cm}$. The grains are smaller than those of pearl millet and vary in color from white to orange-red to deep brown to almost black. Depending on the species, the proximate composition varies. The Fibre content of millets is higher than that of wheat and rice, with Barnyard millet having fifty times the fiber content of rice (Bavec \& Bavec, 2006). Millet is rich in B-group vitamin and also in minerals like potassium, phosphorus, iron, copper, magnesium, zinc and manganese (Adekunle, 2012).

Millets have an oil content of $4.2 \%$ of which $50 \%$ is polyunsaturated. Millets are important cereals besides wheat, rice, and maize. Millets serve as a major food source for millions of people, especially those who live in hot and humid areas of the world such as Nigeria. They are grown mostly in marginal areas under agricultural conditions in which major cereals fail to give substantial yields (Adekunle, 2012).

Millets are important foods in many underdeveloped countries because of their ability to grow under adverse weather conditions such as limited rainfall. In contrast, millet is the major source of energy and protein for millions of peoples especially those with low socio-economic status. It has been reported millet has many nutritive and medical functions (Obilana \& Manyasa, 2002; Yang et al., 2012). The term millet refers to various group of small-seeded cereal crops which are known for their small coarse grains (Weber \& Fuller, 2006). There are about 6000 varieties of millets grown around the world, the four major types are pearl millet (Pennisetum glaucum), which comprises $40 \%$ of the world production, fonio millet (Setaria Italica) (Yang et al., 2012), finger millet (Eleusine coracana) and proso millet or white millet (panicum milliceum). Pearl millet produces the largest seeds and it is the variety most commonly used for human consumption (Mariac et al., 2006; ICRISAT, 2007). Nigeria as a country is faced with the problem of feeding its teeming population; therefore it is important to explore local biodiversity such as millet which is at present underutilized. 


\subsection{MATERIAL AND METHOD}

The millet varieties were obtained from the central markets in Katsina state, Nigeria. All reagents used were of analytical grades and were purchased from a chemical store in Katsina State, Nigeria. The millet varieties (finger millet and pearl millet) were cleaned by washing in water, de-watered, sun-dried, milled into flour and stored in sealed polythene bags.

\subsubsection{Determination of anti-oxidant activity}

\subsubsection{Determination of ferric reducing property}

The reducing property of the extract was determined using method described by Pulido et al., (2000), $0.25 \mathrm{ml}$ of the extract was mixed with $0.25 \mathrm{ml}$ of $200 \mathrm{mM}$ of sodium phosphate buffer $\mathrm{pH} 6.6$ and $0.25 \mathrm{ml}$ of $1 \% \mathrm{~K}_{3} \mathrm{Fe}(\mathrm{CN})_{6}$. The mixture was incubated at $50^{\circ} \mathrm{C} 20$ mins, thereafter $0.25 \mathrm{ml}$ of $10 \%$ TCA was also added and centrifuge at $2000 \mathrm{rpm}$ for $10 \mathrm{mins}, 1 \mathrm{ml}$ of the supernatant was mixed with $1 \mathrm{ml}$ of disttled water and $0.1 \%$ of $\mathrm{FeCl}_{3}$ and the absorbance was measure at $700 \mathrm{~nm}$.

\subsubsection{Determination of DPPH free radical scavenging ability}

The free radical scavenging ability of the extract against DPPH (1,1-diphenyl-2-picryhydrazyl) using Gyamfi et al., (1999) method. One $1 \mathrm{ml}$ of the extract was mixed $1 \mathrm{ml}$ of the $0.4 \mathrm{Mm}$ methanolic solution of the DPPH the mixture was left in the dark for 30 mins before measuring the absorbance at $516 \mathrm{~nm}$. The activity was expressed as percentage DPPH scavenging relative

DPPH Scavenging Activity $(\%)=\frac{\text { Absorbance of control-Absorbance of sample }}{\text { Absorbance of control }} \times 100$

\subsubsection{ABTS 2, 2'- azino-bis (3-ethylbenthiazoline-6-sulphonic acid) scavenging ability}

The ABTS scavenging ability of the extract was determined according to the method described by Re et al., (1999). The ABTS was generated by reacting an $(7 \mathrm{mM})$ ABTS aqueous solution with $\mathrm{K}_{2} \mathrm{~S}_{2} \mathrm{O}_{8}(2.45 \mathrm{mM} / 1$, final conc.) in the dark for $16 \mathrm{hrs}$ and adjusting the absorbance at 734 $\mathrm{nm}$ to 0.700 with ethanol 0.2 of the appropriate dilution of the extract was then added to $2.0 \mathrm{ml}$ of ABTS solution and the absorbance was read at $732 \mathrm{~nm}$ after 15 mins. The TROLOX equivalent antioxidant capacity was subsequently calculated.

\subsubsection{Determination of amino acid profile}

Amino acid analyses was carried out according to the method described by Na et al., (1986). Ground samples were prepared for amino acid determination by acid hydrolysis with $6 \mathrm{NHCl}$ for $24 \mathrm{hrs}$ at $110^{\circ} \mathrm{C}$ in vial under vacuum and $\mathrm{N}_{2}$ atmosphere. Sample solution was evaporated and dissolved in sodium citrate buffer (Ph. 2.2). The hydrolysates were analyzed by a postcolumn derivative method using a High Pressure Liquid Chromatography (HPLC), which was combined with a Pickering PCX5200 derivatizer (Pickering Laboratories, Inc., USA) and ion exchange columm $(3.0 \times 250 \mathrm{~mm}, 8 \mu \mathrm{m})$. The identification of amino acids was spectrometrically performed by measuring at $570 \mathrm{~nm}$.

\subsubsection{Determination of fatty acid profile}

The fatty acid profile was determined using the method described by Ohks, (1994). Fatty acids were extracted using a mixture of chloroform and methanol $(2: 1, \mathrm{v} / \mathrm{v})$ solution. The samples were centrifuged at $3000 \mathrm{rpm}$; the supernatants collected were added with $0.9 \% \mathrm{NaCl}$ solution and centrifuged at $3000 \mathrm{rpm}$. The chloroform phase was evaporated under nitrogen gas treated with $14 \%$ boron trifluoride method solution $\left(\mathrm{BF}_{3}-\mathrm{MeOH}\right)$ for 10 mins at $100^{\circ} \mathrm{C}$. After cooling 
to room temperature, $1.0 \mathrm{ml}$ of water and $2.0 \mathrm{ml}$ of pentane were added. The pentate phase was evaporated under nitrogen gas and dissolved in n-hexane. Fatty acid composition was analyzed using a gas chromatography GC (Acme 6000, Young- Lin Co.), which was equipped with a flame ionization detector (FID) and SPBTM-fused silica capillary column $(130 \mathrm{~mm} \times 1000.25$ $\mathrm{mm}, 0.25 \mu \mathrm{m}$, Supelco Co., USA) nitrogen gas was used for the carrier. The injector and detector temperature were 150 and $280^{\circ} \mathrm{C}$, respectively. The temperature gradient of the GC oven was programmed to be initiated at $180^{\circ} \mathrm{C}$ for $8 \mathrm{mins}$ and raised $3{ }^{\circ} \mathrm{C} / \mathrm{min}$ until it reached a final temperature of $230^{\circ} \mathrm{C}$ for 15 mins. Individual fatty acid methyal esters (FAME) were quantified as a percentage of total FAME analysed.

\subsubsection{Anayses of proximate composition}

Proximate analyses of the samples were carried out using the standard procedures of AOAC, (2005).

\subsubsection{Determination of moisture content}

Moisture content determination was carried out using the air oven (Laboratory oven, Model No: DHG-9101 SA). Petri dishes were washed and dried for minute and cooled in the dessicator for about 20 mins. The petri dishes were weighed $\left(\mathrm{W}_{1}\right)$ and 10 gramme of the sample was added into the dish to give a new weight $\left(\mathrm{W}_{2}\right)$. It was then placed in the oven at $105^{\circ} \mathrm{C}$ for $3 \mathrm{hrs}$, after which it was removed, allowed to cool in the dessicator and oven dried again, this was repeated several times until constant weight was noted $\left(\mathrm{W}_{2}\right)$.

$\%$ Moisture $=\left(W_{2}-W_{3}\right) /\left(W_{2}-W_{1}\right)$

Where

$\mathrm{W}_{1}=$ weight of petri dish

$\mathrm{W}_{2}$ = weight of petri dish + sample before drying

$\mathrm{W}_{3}=$ weight of petri dish + sample after drying

\subsubsection{Determination of Ash content}

Crucible was pre-heated in the oven for $30 \mathrm{mins}$ at $105^{\circ} \mathrm{C}$, cooled in the dessicator for about $1 \mathrm{hr}$ and weighed $\left(\mathrm{W}_{1}\right)$. One gramme of the sample was added into crucible, given a new weight $\left(\mathrm{W}_{2}\right)$

It was then be placed in the muffle furnace for ashing at $55^{\circ} \mathrm{C}$ for $3 \mathrm{hrs}$ until the content became whitish in colour with no black particles, it was removed and cooled in the dessicator, the weight was noted $\left(\mathrm{W}_{3}\right)$.

$\%$ Ash $=\left(W_{2}-W_{3}\right) /\left(W_{2}-W_{1}\right)$

Where

$\mathrm{W}_{1}=$ weight of crucible

$\mathrm{W}_{2}=$ weight of crucible + sample before ashing

$\mathrm{W}_{3}=$ weight of crucible + sample after ashing

\subsubsection{Determination of fat content}

Filter paper free from fat was weight $\left(\mathrm{W}_{1}\right)$. About 1 gramme of the sample was added into the filter paper, carefully folded and tied to keep the sample intact, the new weight noted $\left(\mathrm{W}_{2}\right)$. A $500 \mathrm{ml}$ round bottom flask was filled up to three-quarter with solvent (n-Hexane). The flask was fitted to soxhlet extraction with a reflux condenser and placed on an electo-mantle heater. 
Extraction began as the solvent start refluxing several times. Extraction continued for about 6 hrs after which the condenser was detached, the defatted sample removed, and dried to a constant weight in the oven at $105^{\circ} \mathrm{C}$ for $2 \mathrm{hrs}$. the difference between the weight of the defatted sample before and after drying was recorded as the weight of fat $\left(\mathrm{W}_{3}\right)$.

Fat $(\%)=\left(W_{2}-W_{1}\right) / W \times 100$

\subsubsection{Determination of nitrogen and crude protein}

About $0.5 \mathrm{~g}$ part of the sample were weighed and transferred into a Kjedahl flask. Using a measuring cylinder, about $5 \mathrm{ml}$ concentrated sulphuric acid and one tablets of kjeldhal catalyst were added to the flask. The flask in an inclined position was gently heated in a fume cupboard, using heating mantle. When the initial vigorous reaction has died down, the heat was increased and digestion was continued until the liquid was clear and free from black or brown colour. The flask was allowed to cool and the mixture was transferred to $100 \mathrm{ml}$ volumetric flask, diluted with distilled water to the mark. About $10 \mathrm{ml}$ of the sample aliquot and $15 \mathrm{ml}$ of $40 \%$ Sodium Hydroxide solution was transferred into the distillation apparatus consisting of the flask (500 ml capacity), stopper carrying a dropping funnel and a splash head adaptor: a vertical condenser. Ten (10) $\mathrm{ml}$ of $2 \%$ boric acid solution was measured into a $250 \mathrm{ml}$ conical flask, and a few drops of screened methyl red indicator were added to the flask and then placed on the receiver so that the end of the delivery tube is below the level of the boric acid. A few pieces of granulated zinc and some anti-dumping granules were added to the distillation flask. The apparatus were shaken gently to ensure mixing of the contents. The flask was boiled vigorously until about $25 \mathrm{ml}$ distillate is obtained. The receiver was removed and titrated against a standard acid $0.025 \mathrm{M} \mathrm{H}_{2} \mathrm{SO}_{4}$ till a pink colour end point (TV) is reached.

$$
N(\%)=(0.014 \times T V \times 100 \times 0.025) /(W \times 10) \times 100
$$

Where $\mathrm{W}$ is weight of sample taken.

$\%$ protein $=\mathrm{N} \times \mathrm{F}$

Where $\mathrm{F}$ is a factor equal to 5.70 for flour, 6.38 for milk, 5.55 for gelatine and 6.25 for all other foods.

\subsubsection{Determination of crude fibre}

About 5 grams of the sample were weighed $\left(\mathrm{W}_{1}\right)$ and defatted by ether extraction with Soxhlet apparatus and dried. The sample was transfered quantitatively by brushing in a $600 \mathrm{ml}$ beaker of the fibre digestion apparatus. $200 \mathrm{ml}$ of $1.25 \%$ sulphuric acid was added. The beaker were placed on digestion apparatus with pre adjusted heater and boiled for exactly 30 minutes. The beaker was removed and the contents were filtered through California Buchner funnel. The beaker was rinsed with $75 \mathrm{ml}$ of boiling water and washed through the funnel. The washing was repeated 3 times with $50 \mathrm{ml}$ portion of water and then sucks dry. The residue was returned to the beaker by blowing back through the funnel. $200 \mathrm{ml}$ of boiling and $1.25 \%$ sodium hydroxide was added to the beaker and boiled for 30 minutes and the beaker was removed and filtered. The residue was then washed with $25 \mathrm{ml}$ of boiling 1.25 sulphuric acid, followed by three $50 \mathrm{ml}$ portion of water and $25 \mathrm{ml}$ of alcohol respectively. The fibre mat and the residue were then dried at $130 \pm 2{ }^{0} \mathrm{C}$ for 2 hours. It's then cooled in a desiccator and weighed $\left(\mathrm{W}_{2}\right)$.

It was ignited at $600{ }^{0} \mathrm{C} \pm 15$ for 30 minutes. The dishes were removed and cooled in a desiccator and weighed $\left(\mathrm{W}_{3}\right)$. The Fibre was calculated as follows:

$(\%)$ Crude fibre $=\left(W_{2}-W_{3}\right) /\left(W_{1}\right) \times 100$ 
Where

$\mathrm{W}_{1}=$ weight of sample

$\mathrm{W}_{2}=$ weight of crucible + sample after drying

$\mathrm{W}_{3}=$ weight of crucible + sample after ashing

\subsubsection{Determination of carbohydrate}

Total carbohydrate was calculated by difference using the following formula: Carbohydrate $(\%)=100-(\%$ Moisture $+\%$ Ash $+\%$ Fat $+\%$ Protein $)$

\subsubsection{Determination of mineral composition}

According to method outlined by AOAC, (2005) mineral (manganese, copper, iron, zinc and calcium) content was determined by Atomic Absorption Spectrophotometry (Model 6800 series Shimazo Corp). The ash obtained from the muffle furnace (product of the ash content determination) was dissolved in $10 \mathrm{ml}$ of $10 \%$ HCL. The mixture was heated on a steam bath to effect complete dissolution and the dissolved ash was filtered into a $100 \mathrm{ml}$ volumetric flask and made up to volume with distilled water. The mineral content was determined using an Atomic Absorption Spectrophotometer (Alpha 4-Chem. Tech Analytical, USA).

\subsubsection{Statistical Analyses}

Data were analyzed by one way analysis of variance (ANOVA) using SPSS (16.0) software. Means were compared by the Duncan's multiple range tests (DMRT); significant was accepted. 


\subsection{RESULTS AND DISCUSSION}

\subsection{Amino Acid profile of the millet varieties}

Table 1: Amino acid profile of Finger

\begin{tabular}{|c|c|c|c|c|}
\hline $\mathbf{S} / \mathbf{N}$ & Parameters & $\mathrm{Mg} / 100 \mathrm{~g}$ of Protein & $\%$ of protein & mg/g of Nitrogen \\
\hline 1 & Histidine & $140.25 \pm 0.03$ & 0.15 & 130 \\
\hline 2 & Alanine & $160.34 \pm 0.01$ & 0.39 & \\
\hline 3 & Arginine & $159.08 \pm 0.03$ & 0.27 & 300 \\
\hline 4 & Leucine & $320.06 \pm 0.02$ & 0.55 & 690 \\
\hline 5 & Lysine & $101.04 \pm 0.02$ & 0.21 & 220 \\
\hline 6 & Cysteine & $26.35 \pm 0.02$ & 0.14 & 140 \\
\hline 7 & Methionine & $86.33 \pm 0.03$ & 0.21 & 210 \\
\hline 8 & Phynylalanine & $160.26 \pm 0.01$ & 0.32 & 310 \\
\hline 9 & Threonine & $142.26 \pm 0.01$ & 0.26 & 240 \\
\hline 10 & Glycine & $165.35 \pm 0.02$ & 0.24 & \\
\hline 11 & Tryptophan & $26.36 \pm 0.01$ & 0.09 & 100 \\
\hline 12 & Proline & $205.56 \pm 0.02$ & 0.36 & \\
\hline 13 & Valine & $142.26 \pm 0.01$ & 0.45 & 480 \\
\hline 14 & Serine & $162.26 \pm 0.01$ & 0.33 & \\
\hline 15 & Tyrosine & $136.34 \pm 0.02$ & 0.19 & 220 \\
\hline 16 & Isoleucine & $155.24 \pm 0.03$ & 0.23 & 400 \\
\hline 17 & Aspatic Acid & $163.34 \pm 0.02$ & 0.39 & \\
\hline 18 & Glutamic Acid & $22.24 \pm 0.03$ & 1.00 & \\
\hline
\end{tabular}

NB: $*$ = Value obtained from Data Analyses

$* * *=$ Value obtained from literature (Kunyanga et al., 2013)

***= Value obtained from literature (Goplan et al., 2009)

The amino acid profile of finger millet as shown in table 1 above as follow; histidine $(140.25 \mathrm{mg} / 100 \mathrm{~g})$, alanine $\quad(160.34 \mathrm{mg} / 100 \mathrm{~g})$ arginine $\quad(159.08 \mathrm{mg} / 100 \mathrm{~g})$,leucine $(320.06 \mathrm{mg} / 100 \mathrm{~g})$, lysine $(101.04 \mathrm{mg} / 100 \mathrm{~g})$, cysteine $(26.35 \mathrm{mg} / 100 \mathrm{~g})$, methionine $(86.33 \mathrm{mg} / 1$ $00 \mathrm{~g})$, phenylalanine $(160.26 \mathrm{mg} / 100 \mathrm{~g})$, threonine $(142.26 \mathrm{mg} / 100 \mathrm{~g})$, glycine $(165.35 \mathrm{mg} / 100 \mathrm{~g})$, tryptophan $(26.36 \mathrm{mg} / 100 \mathrm{~g})$, proline $(205.56 \mathrm{mg} / 100 \mathrm{~g})$, valine $(142.26 \mathrm{mg} / 100 \mathrm{~g})$, serine 
$(162.26 \mathrm{mg} / 100 \mathrm{~g})$, tyrosine $(136.34 \mathrm{mg} / 100 \mathrm{~g})$, isoleucine $(155.24 \mathrm{mg} / 100 \mathrm{~g})$, aspartic acid $(163.34 \mathrm{mg} / 100 \mathrm{~g})$ and glutamic acid $(22.24 \mathrm{mg} / 100 \mathrm{~g})$.

Table 2: Amino acid profile of Pearl Millet

\begin{tabular}{|c|c|c|c|c|c|}
\hline $\begin{array}{l}\mathrm{S} / \\
\mathrm{N}\end{array}$ & Parameters & $\begin{array}{l}\text { Mg/100g of Prot } \\
\text { en }\end{array}$ & $\begin{array}{l}\% \text { of prote } \\
n\end{array}$ & $\begin{array}{l}\text { mg/g of Nitrog } \\
\text { en }\end{array}$ & $\begin{array}{l}\mathrm{Mg} / \mathrm{g} \text { of Nitrog } \\
\text { en }\end{array}$ \\
\hline 1 & Histidine & $140.25 \pm 0.03$ & 0.15 & 130 & 140 \\
\hline 2 & Alanine & $160.34 \pm 0.01$ & 0.39 & & \\
\hline 3 & Arginine & $159.08 \pm 0.03$ & 0.27 & 300 & \\
\hline 4 & Leucine & $320.06 \pm 0.02$ & 0.55 & 690 & 300 \\
\hline 5 & Lysine & $101.04 \pm 0.02$ & 0.21 & 220 & 750 \\
\hline 6 & Cysteine & $26.35 \pm 0.02$ & 0.14 & 140 & 190 \\
\hline 7 & Methionine & $86.33 \pm 0.03$ & 0.21 & 210 & 110 \\
\hline 8 & $\begin{array}{l}\text { Phynylalanin } \\
\text { e }\end{array}$ & $160.26 \pm 0.01$ & 0.32 & 310 & 150 \\
\hline 9 & Threonine & $142.26 \pm 0.01$ & 0.26 & 240 & 290 \\
\hline 10 & Glycine & $165.35 \pm 0.02$ & 0.24 & & 240 \\
\hline 11 & Tryptophan & $26.36 \pm 0.01$ & 0.09 & 100 & \\
\hline 12 & Proline & $205.56 \pm 0.02$ & 0.36 & & 110 \\
\hline 13 & Valine & $142.26 \pm 0.01$ & 0.45 & 480 & \\
\hline 14 & Serine & $162.26 \pm 0.01$ & 0.33 & & 410 \\
\hline 15 & Tyrosine & $136.34 \pm 0.02$ & 0.19 & 220 & 200 \\
\hline 16 & Isoleucine & $155.24 \pm 0.03$ & 0.23 & 400 & 260 \\
\hline 17 & Aspatic Acid & $163.34 \pm 0.02$ & 0.39 & & \\
\hline 18 & $\begin{array}{l}\text { Glutamic Aci } \\
\text { d }\end{array}$ & $22.24 \pm 0.03$ & 1.00 & & \\
\hline
\end{tabular}

NB: * = Value obtained from Data Analyses

***= Value obtained from literature (Kunyanga et al., 2013)

$* * *=$ Value obtained from literature Azhari et.,al (2015)

****= Value obtained from literature (Goplan et al., 2009) 
Table 2: Above shows the various amino acid present in pearl millet as follow; histidine $(133.35 \mathrm{mg} / 100 \mathrm{~g})$, alanine $(162.25 \mathrm{mg} / 100 \mathrm{~g})$, arginine $(152.26 \mathrm{mg} / 100 \mathrm{~g})$, leucine $(308.85 \mathrm{mg} / 1$ $00 \mathrm{~g})$, lycine $(93.64 \mathrm{mg} / 100 \mathrm{~g})$, cysteine $(23.36 \mathrm{mg} / 100 \mathrm{~g})$, methionine $(80.45 \mathrm{mg} / 100 \mathrm{~g})$, phenylalanine $(155.45 \mathrm{mg} / 100 \mathrm{~g})$, threonine $(133.37 \mathrm{mg} / 100 \mathrm{~g})$, glycine $(160.25 \mathrm{mg} / 100 \mathrm{~g})$, trypt ophan $(20.38 \mathrm{mg} / 100 \mathrm{~g})$, proline $(212.26 \mathrm{mg} / 100 \mathrm{~g})$, valine $(124.27 \mathrm{mg} / 100)$, serine $(135.37 \mathrm{mg} / 100 \mathrm{~g})$, tyrosine $(121.16 \mathrm{mg} / 100 \mathrm{~g})$, isoleucine $(140.13 \mathrm{mg} / 100 \mathrm{~g})$, aspartic acid (138.34mg/100), and glutamic acid (19.34mg/100g).

Amino acid profile of a food material is a function of its protein quality. The millet varieties were found to be rich sources of essential amino acid such as valine, isoleucine, histidine, methionine, tryptophan, threonine, lysine and phenylalanine which are required for vital body processes (Kunyanga et al., 2013; Azhari et al., 2015; Glew et al., 2013; Chukwu and Abdulkadir, 2008). Though millets are said to be limited in lysine like other cereals, they are excellent source of the sulphur containing amino acids; methionine and cysteine, two human-vital amino acids almost deficient in the major cereals like sorghum, rice, wheat or barley (Fliedel et al., 2004). This two amino acids supply sulphur and other compounds required by the body for normal metabolism and growth (De- Lumen et al., 1993).

\subsection{Fatty Acid Profile of the Millet Varieties}

Table 3: Fatty Acid Profile of Finger millet

\section{S/N Parameters}

\begin{tabular}{lccccc}
\hline 1 & Stearic Acid (\%) & $1.20 \pm 0.01$ & $4.80 \pm 0.35$ & 0.58 & \\
2 & Palmitic Acid (\%) & $18.17 \pm 0.05$ & $20.80 \pm 0.01$ & 23.06 & 25.00 \\
3 & Oleic Acid (\%) & $22.19 \pm 0.02$ & $38.40 \pm 0.09$ & 47.17 & 49.00 \\
4 & Linolei Acid (\%) & $48.05 \pm 1.43$ & $20.30 \pm 0.00$ & 24.78 & 25.00 \\
5 & Stearic Acid (\%) & $1.20 \pm 0.01$ & $4.80 \pm 0.35$ & 0.58 & \\
\hline & & $*$ & $* *$ & $* * *$ & $* * * *$
\end{tabular}

NB: * = Value obtained from Data Analyses

$* *=$ Value obtained from literature (Kunyanga et al., 2013)

$* * *=$ Value obtained from literature (Poonia et al., 2012)

$* * * *=$ Value obtained from literature (Gull et al., 2015)

Table 3 shows the fatty acid profile of finger millet as follow; stearic acid (1.20\%), palmitic acid $(18.17 \%)$, oleic acid (22.10\%) and linoleic acid (48.05\%). 


\section{Table 4: Fatty Acid Profile of Pearl millet}

\begin{tabular}{llllll}
\hline $\mathbf{S} / \mathbf{N}$ & Parameters & & & \\
\hline 1 & Stearic Acid (\%) & $1.27 \pm 0.01$ & 5.00 & 3.90 & \\
2 & Palmitic Acid (\%) & $18.34 \pm 0.02$ & 19.00 & 20.30 & 20.60 \\
3 & Oleic Acid (\%) & $22.26 \pm 0.01$ & 25.00 & 26.70 & 28.54 \\
4 & Linolei Acid (\%) & $45.57 \pm 0.03$ & 46.00 & 45.30 & 45.55 \\
& & & & & \\
5 & Stearic Acid (\%) & $1.27 \pm 0.01$ & 5.00 & 3.90 & \\
\hline & & $*$ & $* *$ & $* * *$ & $* * *$
\end{tabular}

NB * = Value obtained from Data Analyses

**= Value obtained from literature Rooney, (2006)

$* * *=$ Value obtained from literature RIRDC (2013)

$* * * *=$ Value obtained from literature Daniel et at., (2015)

Table 4 shows the fatty acid profile of pearl millet determined in this work as follows; stearic acid (1.27\%), palmitic acid (18.34\%), oleic acid (22.26\%) and linoleic acid (45.57\%).

The studied millet varieties contained bulk amount of unsaturated fatty acids namely oleic and linoleic fatty acid which accounts for $(70 \%-75 \%)$ of the total fatty acid with some small amount of saturated acids such as palmitic and stearic acid. This is in agreement with the works of several researchers (Poonia et al., 2012; Kunyanga et al., 2013; Glew et al., 2013; Fliedel et al., 2004). These unsaturated fatty acid of great health importance, linoleic acid which is an omega 6-fatty acids, is highly significant because this acid is easily converted to $n-6$ eicosanoids, $n-6$ prostaglandin and n-6 leucotriene hormones. These are all of great importance in drug development etc. linoleic acid is also very popular in beauty products as it helps in moisture retention, acne reduction, and treatment of inflammatory related diseases. Lack of linoleic acid causes dry hair, hair loss and wound healing. Therefore, the consumption of these millet varieties will yield the same advantages to the consumer. Oleic acid, which is an omega- 9 fatty acid as a major fatty acid also is equally important having all the health benefits of linoleic acid. In cases of reduced availability of omega-6-fatty acids, omega-9-fatty acids are converted to omega-6-fatty acids (Poonia et al., 2012). 


\subsection{Phytochemical Properties of the Millet Varieties}

Table 5: Phytochemical Properties of Finger Millet

\begin{tabular}{|c|c|c|c|c|}
\hline $\mathrm{S} / \mathrm{N}$ & Parameters & & & \\
\hline 1 & Tannin (mg/g) & $7.70 \pm 0.02$ & $0.40(\%)$ & $1.60 \pm 0.10$ \\
\hline 2 & Terpenoid (mg/g) & $11.92 \pm 0.01$ & & \\
\hline 3 & Alkaloid (\%) & $72.83 \pm 0.03$ & & \\
\hline 4 & Cardiac glycoside $(\mathrm{mg} / \mathrm{g})$ & $12.32 \pm 0.04$ & & \\
\hline 5 & Saponin (mg/g) & $28.00 \pm 0.04$ & & $5.40 \pm 0.00$ \\
\hline 6 & Oxalate (mg/g) & $0.63 \pm 0.01$ & & $0.68 \pm 0.00$ \\
\hline 7 & Phytate (mg/g) & $18.54 \pm 1.24$ & $\begin{array}{l}260.00 \\
(\mathrm{mg} / 100 \mathrm{~g})\end{array}$ & $3.10 \pm 0.01$ \\
\hline 8 & Flavonoid (mg/g) & $1.70 \pm 0.02$ & & \\
\hline 9 & Total phenol (mg/g) & $2.61 \pm 0.02$ & & \\
\hline
\end{tabular}

NB: $*$ = Value obtained from Data Analyses

**= Value obtained from literature Shashi et al., (2007)

***= Value obtained from literature Rotimi, (2011)

The phytochemical properties of finger millet determined in this work is shown in Table 5 above as follows; Tannin $(7.70 \mathrm{mg} / \mathrm{g})$, Terpenoid $(11.92 \mathrm{mg} / \mathrm{g})$, Alkaloid $(72.83 \%)$, Cardiac glycoside $(12.32 \mathrm{mg} / \mathrm{g})$, Saponin $(28.00 \mathrm{mg} / \mathrm{g})$, Oxalate $(0.63 \mathrm{mg} / \mathrm{g})$, Phytate $(18.54 \mathrm{mg} / \mathrm{g})$, Flavonoids $(1.70 \mathrm{mg} / \mathrm{g})$ and Total Phenol $(2.61 \mathrm{mg} / \mathrm{g})$. 
Table 6: Phytochemical Properties of Pearl Millet

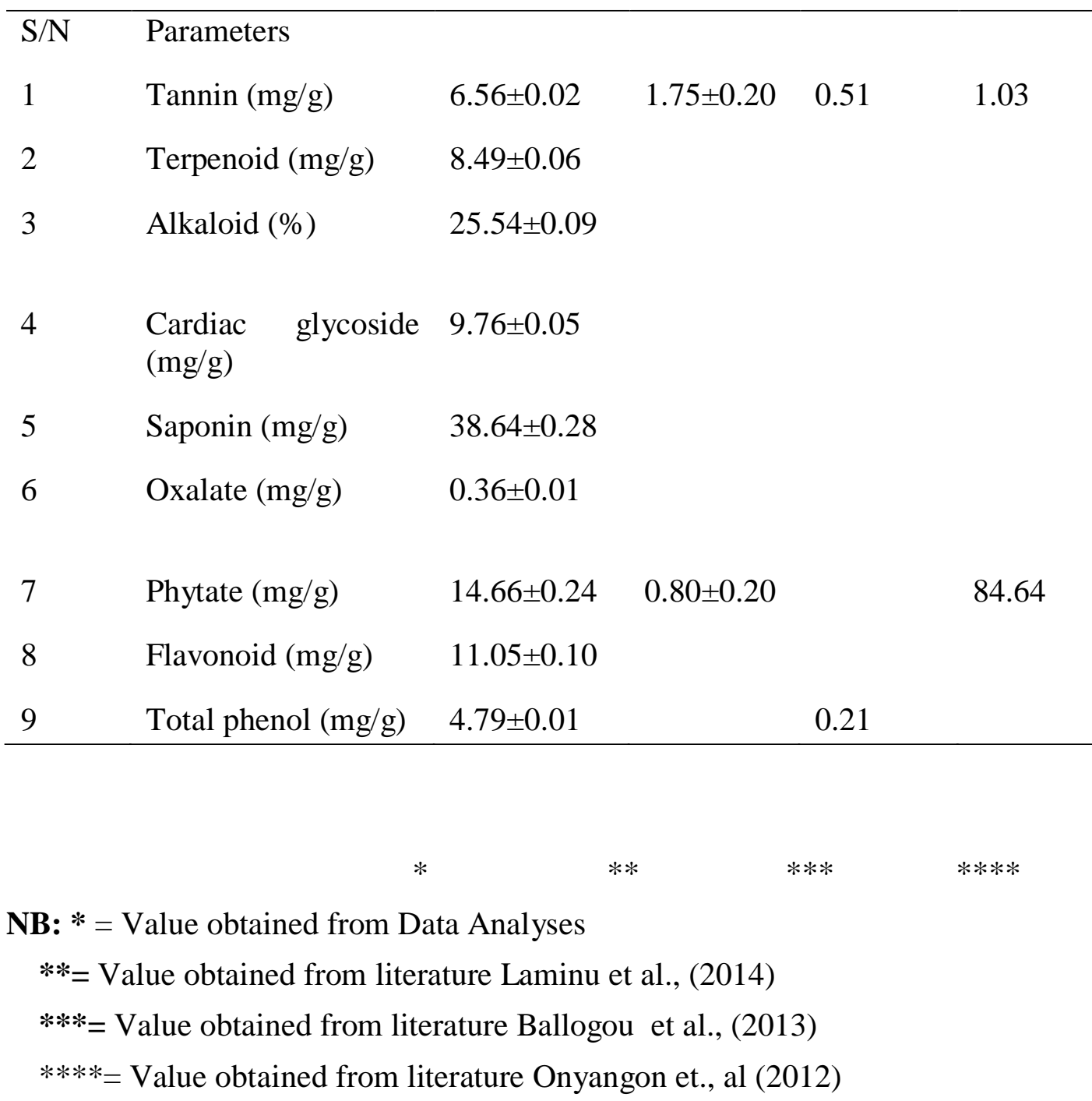

Table 6 shows the phytochemical constituents of pearl millet as determined in this work as follows; Tannin $(6.56 \mathrm{mg} / \mathrm{g})$, Terpenoid $(8.49 \mathrm{mg} / \mathrm{g})$, Alkaloid $(25.54 \%)$, Cardiac glycoside $(9.76 \mathrm{mg} / \mathrm{g})$, Saponin $(38.64 \mathrm{mg} / \mathrm{g})$, Oxalate $(0.36 \mathrm{mg} / \mathrm{g})$, phytate $(14.66 \mathrm{mg} / \mathrm{g})$, Flavoviods $(11.05 \mathrm{mg} / \mathrm{g})$ and Total Phenol $(4.79 \mathrm{mg} / \mathrm{g})$.

Phytochemical screening and quantification of the studied varieties millets reveals the presence of different types of plant bioactive substances such as; tannin, terpenoid, alkaloids, cardiacglycosides, saponin, oxalates, flavonoids and total phenol. Some of these bioactive substances in food could limit the bio availability (hence called anti-nutrients) while others (e.g flavonoids and total phenols which are known for their anti-nutrients activity) could be of great health importance ( Shashi et al., 2007). Though the incidence of these anti-nutrients which are high in the studied varieties has been reported to be reduced to the barest minimum levels by simple processing methods such as cooking, soaking, milling, fermentation, extrusion, alkali and acidic treatments, e.t.c. (Fasasi, 2009). 


\subsection{Antioxidant properties of the Millet Varieties}

Table 7: Antioxidant properties of finger millet

\begin{tabular}{lllll}
\hline S/N & Parameters & & & \\
1 & DPPH (\%) & $67.06 \pm 0.04$ & $1.73(\mathrm{mg} / \mathrm{g})$ & $\begin{array}{l}63.00 \\
(\mu \mathrm{g} / \mathrm{ml})\end{array}$ \\
2 & FRAP $(\mathrm{mg} / \mathrm{g})$ & $20.86 \pm 0.05$ & $471.71(\mathrm{~mol} / \mathrm{g})$ & \\
& & & & \\
3 & ABTS $(\mathrm{mMol} / \mathrm{g})$ & $0.02 \pm 0.01$ & $(\mathrm{ug} / \mathrm{m} /)$
\end{tabular}

*

NB: $*$ = Value obtained from Data Analyses

**= Value obtained from literature Sreeramulu et al., (2009)

***= Value obtained from literature Banerjee et al., (2012)

The antioxidant properties of finger millet as determined is presented in Table 7 values obtained for the various antioxidant test are as follow; DPPH $(67.06 \%)$, FRAP $(20.86 \mathrm{mg} / \mathrm{g})$, and ABTS $(0.02 \mathrm{mMol} / \mathrm{g})$.

Table 8: Antioxidant properties of pearl millet

\begin{tabular}{|c|c|c|c|c|c|}
\hline $\mathrm{S} / \mathrm{N}$ & Parameters & & & & \\
\hline 1 & DPPH (\%) & $61.80 \pm 0.10$ & $51.70(\%)$ & $83.20(\%)$ & $68.10(\%)$ \\
\hline 2 & FRAP (mg/g) & $25.75 \pm 0.02$ & $\begin{array}{l}669.33 \quad(\mathrm{mg} \\
\mathrm{AAE} / \mathrm{g})\end{array}$ & $\begin{array}{l}404.20 \quad(\mathrm{mg} \\
\mathrm{TE})\end{array}$ & $\begin{array}{l}3.16 \quad(\mathrm{Mmol} \\
\mathrm{Fe}_{2} \mathrm{E} / \mathrm{g}\end{array}$ \\
\hline 3 & ABTS (mMol/g) & $0.02 \pm 0.01$ & 3.125 (TE) & & \\
\hline
\end{tabular}

NB: * = Value obtained from Data Analyses

$* *=$ Value obtained from literature Kaddafi et al., (2015)

***= Value obtained from literature Minaxi et al., (2013)

$* * * *=$ Value obtained from literature Singh et al., (2013)

Table 8 shows the antioxidant properties of pearl millet with values obtained for the various antioxidant test as follow; DPPH (61.80\%), FRAP $(25.75 \mathrm{mg} / \mathrm{g})$ and ABTS $(0.02 \mathrm{mMol} / \mathrm{g})$.

The result obtained in this study, revealed that extract from the millet varieties possesses ability to serve as reducing agent and therefore can serve as a source of antioxidants which counter the accumulation of free radicals in the body, free radicals are organic materials that antagonize the proper functioning of body metabolism. 
This finding agrees with the report of (Sies, 1993) that antioxidants are reducing agents. The result also agrees with the finding of (Oboth and Rocha, 2007) on reducing power of pepper. Phenols and phenolic compounds have been reported to possess significant antioxidant activities (Aiyegoro and Okoh, 2009) and since whole millet grain varieties were considered which are believed to be rich in phenolic compounds, hence their antioxidant property is influenced. The total phenolic content of these millet varieties are higher than what was reported by (Oboh et al., 2008) for fermented African locust bean. This indicates that regular consumption of these millet varieties may serve as a dietary source of antioxidants. Also, the values obtained were higher than what was obtained for Carica papaya and Cajanus cajan by (Imaga et al., 2009). Plants with antioxidant activities have been reported to possess free radicals scavenging activity, free radicals are the major contributors to severe diseases and disorders such as cancer, diabetes, liver disease, renal failure and degenerative diseases.

\subsection{Proximate Nutrient Composition of Selected Millet}

Table 9: Proximate Nutrient Composition of Finger millet (wet basis)

\begin{tabular}{lcccr} 
Parameters & \multicolumn{3}{l}{} & \\
Protein (\%) & $10.09 \pm 0.02$ & $14.00 \pm 0.01$ & $10.66 \pm 0.18$ & $5.68 \pm 0.51$ \\
Ash $(\%)$ & $1.94 \pm 0.17$ & $4.22 \pm 0.01$ & $2.84 \pm 0.13$ & $2.21 \pm 0.05$ \\
Fibre (\%) & $3.21 \pm 0.02$ & $3.51 \pm 0.01$ & $3.94 \pm 0.36$ & $4.34 \pm 0.10$ \\
Fat (\%) & $3.24 \pm 0.22$ & $5.28 \pm 0.04$ & $1.42 \pm 0.11$ & $1.68 \pm 0.62$ \\
Moisture (\%) & $8.34 \pm 0.07$ & $10.21 \pm 0.04$ & $7.67 \pm 0.45$ & $11.52 \pm 0.08$ \\
Carbohydrate (\%) $73.18 \pm 0.43$ & $62.78 \pm 0.01$ & $73.47 \pm 0.01$ & $75.83 \pm 0.02$ \\
& & & & $* * *$ \\
\end{tabular}

NB: * = Value obtained from Data Analyses

$* *=$ Value obtained from literature Rotimi, (2011)

***= Value obtained from literature Banusha and Vasantharuba (2013)

$* * * *=$ Value obtained from literature Kunyanga et al., (2013

Table 9 shows the proximate composition of finger millet (as determine in this work) as follows; protein $(10.09 \%)$, ash $(1.94 \%)$, fibre $(3.21 \%)$, fat (3.24), moisture $(8.34 \%)$ and carbohydrate $(73.18 \%)$. The protein content was found to be higher than that obtained by Kunyanga et al. (2013) but lower than the $14 \%$ obtained by Rotimi (2011). The Fibre and ash content was found to be lower than the values reported by Rotimi (2011), Banusha and Vasantharuba (2013) and Kunyanga et al., (2013). The fat content was found to be higher than what was reported by Banusha and vasanthara (2013) but lower than 5.28\% reported by Rotimi (2011).

Table 10: Proximate Nutrient Composition of pearl millet (wet basis) 


\begin{tabular}{lcccc}
\hline Protein $(\%)$ & $10.41 \pm 0.80$ & $12.99 \pm 0.03$ & 10.74 & $12.00 \pm 0.06$ \\
Ash $(\%)$ & $1.70 \pm 0.18$ & $3.21 \pm 0.15$ & 0.74 & $1.60 \pm 0.06$ \\
Fibre (\%) & $3.24 \pm 0.16$ & $2.83 \pm 0.23$ & 3.17 & $2.40 \pm 0.04$ \\
Fat $(\%)$ & $4.43 \pm 0.08$ & $7.96 \pm 0.58$ & 3.47 & $2.80 \pm 0.05$ \\
Moisture (\%) & $8.66 \pm 0.19$ & $4.96 \pm 0.10$ & 10.34 & $10.70 \pm 0.20$ \\
& & & & $70.50 \pm 0.10$ \\
\hline
\end{tabular}

NB: $*$ = Value obtained from Data Analyses

**= Value obtained from literature Laminu et al. (2014)

$* * *=$ Value obtained from literature Akeredolu et al., (2005)

$* * * *=$ Value obtained from literature Onyango et al., (2012)

Table 10 shows the proximate composition of pearl millet as determined in this work as follows; protein $(10.41 \%)$, ash $(1.70 \%)$, Fibre $(3.24 \%)$, fat $(4.43 \%)$, moisture $(8.66 \%)$ and carbohydrate (71.56). The protein content was lower than the values obtained by Laminu et al. (2014), Akeredolu et al. (2005) and Onyango et al., (2012). The Fibre content was also higher than the values obtained by these researchers while the fat content was higher then the values reported by Onyango et al., (2012) but lower than the 7.96\% by Laminu et al., (2014).

\subsection{Mineral Composition of Selected Millet}

Table 11: Mineral Composition of Finger millet

Parameters

$\begin{array}{lllll}\text { Magnesium }(\mathrm{mg} / 100 \mathrm{~g}) & 6.38 \pm 0.02 & 124.00 \pm 0.08 & 168.78 \pm 38.44 & 66.00 \\ \text { Manganese }(\mathrm{mg} / 100 \mathrm{~g}) & 2.85 \pm 0.02 & & 28.35 \pm 13.70 & \\ \text { Zinc }(\mathrm{mg} / 100 \mathrm{~g}) & 0.48 \pm 0.01 & 1.95 \pm 0.05 & 1.80 \pm 0.43 & 1.87 \\ \text { Iron }(\mathrm{mg} / 100 \mathrm{~g}) & 1.46 \pm 0.01 & 2.70 \pm 0.01 & 26.90 \pm 18.03 & 3.84 \\ \text { Copper }(\mathrm{mg} / 100 \mathrm{~g}) & 0.06 \pm 0.01 & & 0.62 \pm 0.18 & \\ \text { Sodium }(\mathrm{mg} / 100 \mathrm{~g}) & 3.70 \pm 0.10 & 0.98 \pm 0.04 & & 0.60 \\ \text { Calcium }(\mathrm{mg} / 100) & 137.33 \pm 1.53 & 319.00 \pm 0.01 & 256.52 \pm 77.85 & 281.00 \\ \text { Potassium }(\mathrm{mg} / 100) & 35.19 \pm 0.42 & & & 294.00 \\ \text { Phosphorus }(\mathrm{mg} / 100) & 158.43 \pm 048 & 245.00 \pm 0.01 & 121.83 \pm 43.32 & 280.00 \\ & & & & * * *\end{array}$

NB: * = Value obtained from Data Analyses

**= Value obtained from literature Kunyanga et al. (2013)

***= Value obtained from literature Shimelish et al., (2009)

$* * * *=$ Value obtained from literature Shashi et al., (2007) 
The mineral composition of finger millet compared with literature values is shown in Table 11 with the following respective values obtained; magnesium $(6.3 \mathrm{mg} / 100)$, manganese $(2.85 \mathrm{mg} / 100)$, zinc $(0.48 \mathrm{mg} / 100)$, iron $(1.46 \mathrm{mg} / 100)$, copper $(0.06 \mathrm{mg} / 100 \mathrm{~g})$, sodium $(3.70 \mathrm{mg} / 100 \mathrm{~g})$, calcium $(137.33 \mathrm{mg} / 100)$, potassium $(35.19 \mathrm{mg} / 100 \mathrm{~g})$ and phosphorus $(158.43 \mathrm{mg} / 100 \mathrm{~g})$. The values obtained suggest that magnesium, phosphorus, potassium and calcium are the bulk of elements in finger millet, this agrees with the report of kunyanga et al., (2013) and shimelis et al., (2009).

Table 12. Mineral Composition of pearl millet

Parameters

\begin{tabular}{lllcc}
\hline Magnesium $(\mathrm{mg} / 100 \mathrm{~g})$ & $4.20 \pm 0.20$ & 97.00 & $177.45 \pm 0.04$ & $93.00 \pm 0.00$ \\
Manganese $(\mathrm{mg} / 100 \mathrm{~g})$ & $0.20 \pm 0.10$ & & & $1.32 \pm 0.00$ \\
Zinc $(\mathrm{mg} / 100 \mathrm{~g})$ & $0.19 \pm 0.01$ & & $6.43 \pm 074$ & $1.79 \pm 0.01$ \\
Iron $(\mathrm{mg} / 100 \mathrm{~g})$ & $1.25 \pm 0.01$ & 8.80 & $9.27 \pm 0.24$ & $10.70 \pm 0.09$ \\
Copper $(\mathrm{mg} / 100 \mathrm{~g})$ & $0.09 \pm 0.01$ & & & $0.62 \pm 0.00$ \\
Sodium $(\mathrm{mg} / 100 \mathrm{~g})$ & $5.10 \pm 0.10$ & 9.20 & $112.12 \pm 0.29$ & $16.25 \pm 0.00$ \\
Calcium $(\mathrm{mg} / 100 \mathrm{~g})$ & $24.13 \pm 0.83$ & 42.00 & $50.07 \pm 0.31$ & $52.78 \pm 0.48$ \\
Potassium $(\mathrm{mg} / 100 \mathrm{~g})$ & $24.13 \pm 0.83$ & 30.00 & $325.35 \pm 0.23$ & $434.26 \pm 0.00$ \\
Phosphorus $(\mathrm{mg} / 100 \mathrm{~g})$ & $121.35 \pm 0.56$ & 360.00 & $399.23 \pm 0.04$ & $1106.77 \pm 1.76$
\end{tabular}

NB: $*$ = Value obtained from Data Analyses

**= Value obtained from literature Fasasi, (2013)

***= Value obtained from literature Laminu et al., (2009)

$* * * *=$ Value obtained from literature Abdelrahman et al., (2007)

Table 12. shows the mineral composition of pearl millet (as determined in this work) as follows; magnesium $(4.20 \mathrm{mg} / 100 \mathrm{~g})$, manganese $(0.20 \mathrm{mg} / 100 \mathrm{~g})$, zinc $(0.19 \mathrm{mg} / 100 \mathrm{~g})$, iron $(1.25 \mathrm{mg} / 100 \mathrm{~g})$, copper $(0.09 \mathrm{mg} / 100 \mathrm{~g})$, sodium $(5.10 \mathrm{mg} / 100 \mathrm{~g})$, calcium $(115.54 \mathrm{mg} / 100 \mathrm{~g})$, magnesium, phosphorus, potassium and calcium are the bulk of elements in pearl millet, this agrees with the report of fasasi, (2009) and Abdelrahman et al., (2005).

\section{CONCLUSION}

The results obtained from this work showed that the selected millet varieties (finger millet, pearl millet and fonio) are all good sources of essential nutrients which could make substantial contribution to the intakes of phytochemical and antioxidant. Consequently, these selected millet varieties when properly utilized through effective products development programs, have the potential of helping in overcoming malnutrition and hunger among the vulnerable groups in Nigeria. 


\section{REFERENCES}

Abdalla, A.A. (2013). Evaluation of biochemical and nutritional profile during processing of department of food science and technology, university of kharton, sudan.

Adekunle, A. A. (2012). Agriculture innovation in sub-sahara Africa: experiences from multiple stake holder approaches. Forum for Agricultural Research in African, Ghana. ISBN 978-99881-2-4.

Anounye, J. C., Onuh, J. O., Egwim, E. and Adeyemo, S. O. (2010). Nutrient and anti-nutrient composition of extruded acha/soybean blends. Journal of food processing and preservation, 34:680-691.

Azhari, A.M., Isam, A.M., Elfadil, E.B., Mohamed, M.I. and Waled, A.M. (2015). Effect of supplementation and processing on amino acids composition and score of pearl millet flour. American journal of food science and health, 1(3):86-91.

Ballogou, V. Y., Soumanou, M.M., Toukourou, F and Hounhourgan J.D. (2013). Nutritional composition of Fonio (Digitaria exilis) grains. International Research Journal of Biological Sciences 2(1) 73-79.

Banerjee, S., Sanjay, K.R., Chethan, S. and Malleshi, N.G. (2012). Finger millet (Eleusine coracona) polyphenols investigation of their antioxidant capacity and anti-microbial activity. African journal of food science, 6(13):362-374.

Bavec, F and Bavec, M. (2002). Millets in Organic production and Use of Alternative Crops, CRC Press, London, NY, chapter 4.

Brunner, J.H. (1994). Direct spectrophometerdetermination of saponin. Animal Chemistry 34: 1314-1326.

Chukwu, O. and Abdulkadir, A.J. (2008). Proximate chemical composition of Acha (Digitaria exilis and Digitaria ibura) grains. Journal of food Technology, 6(5):214-216.

Daniel, M., Denni, M., and Chauchan, D. (2012). Polyphenols, Phospholipids and fixed oil composition of pearl millet (Pennisetum glaucum L.) international journal of pharmacy and life sciences, 3(11):2098-2102.

De-Lumen B.O., Thompson S. and Odegard J.W. (1993). Sulphur amino acid-rich proteins in acha (Digitaria exilis), a promising underutilized African cereal. Journal of Agriculture food chemistry 41: 1045-1047.

Echendu, C.A., Obizobz, I.C., Anyika, J. U., and Ojimelukwe, P.C. (2009). Changes in Chemical Composition of treated and untrated hungry rice "Acha" (Digitaria exilis). Pakistan journal of nutrition, 8(11):1779-1785.

Fasasi, O.S. (2009). Proximate, antinutritional factors and functional properties of processed pearl millet (pennisetum glaucum). Journal of food technology, 7 (3):92-97.

Fliedel G., Ouattara M., Grabulos J., Drame D., and Cruz J. (2004). Effect du blanchiment mecanique sur la qualite technologique, culinaire et nutritionnnelle du fonio, cereal d' Afrique de 1'Ouest. In: Brouwer Inge D., Traore Alfred S. and Treche S., (edition) Voies alimentaaires d' amelioration des situations nutritionnistes en Afrique de 1'Ouest: Le role des technologies alimentaires et des nutritionnistes: actes du 2e Atelier international, Ouagadougou, 23-28 nov.2003. Ouagadougou: actes du 2e Atelier 
international, Ouagadougou, 23-28 nov. 2003. Ouagadougou: Presses universitaires de Ouagadougou, Burkina Faso, 599-614.

Glew, R.H., Laqbes, E.P., Presley, J.M., Schulze, J., Andrews, R., Wang, Y., Chang, Y., and Chuang, L. (2013). Fatty acid, amino acid, mineral and antioxidant content of Acha (Digitaria exilis) grown on the Jos plateau, Nigeria. International journal of nutrition and metabolism, 5(1):1-8.

Gopalan, C., Rama Sastri, B. V., and Balasubramanian, S. C. (2009). Nutritive value of Indian foods. Hyderabad, India: National Institute of Nutrition, Indian Council of Medical Research.

Gull, A., Nayik, G. A., Prasad, K and Kumar, P. (2015). Biodiversity and nutraceutical quality of some indian millets. Proceedings of the National Academy of Sciences, india Section B: Biological Sciences, 82:265-273.

Gyamfi, M.A. Yonamine, M. and Aaniya, Y. (1995). Free radical scavenging action of medicinal herbs from Ghana: thonningia sanguine on experimentally induced liver injuries. General Pharmacology., 32:661-667.

Harborne, J.B. (1973). Phytochemical method, Chapman and Hall, London, Pp. 11-12.

Kaddafi, A., Faouzi, Y., Omar, C., and Bouchra, M. (2015). In vitro antioxidant and antiinflammatory activities of extracts of pearl millet (Pennisetum glaucum L.). Journal of chemical and pharmaceutical research, 7(6):1-6.

Kunyanga, C.N., Imungi, J.K., and Vellingiri, V. (2013). Nutritional evaluation of indigenous foods with potential food-based solution to alleviate hunger and malnutrition in kenya. Journal of applied bioscience 67:5277-5288.

Laminu, H.H., Modu, S. and Muhammad, A.A (2014). Evaluation of chemical composition, antinutrients and mineral element level of a composite meal from peal millet, wheat, cowpea and groundnut. Sky journal of food science, 3(6):61-70.

Mariac, C., Luong, I., Kapran, A., Mamadous, F., Sagnard M., Deu, J., Chantereau, B.,Gerard, J., Ndjeunga, G., Bezanco, j., pham, V and Vigourous, Y. (2006). Diversity of wild and cultivated pearl millet accessions (pennisetum glaucum [L.] R. Br.) in Niger assessed by microsatellite markers. Theor. Appl. Genet. 114:49-58.

Marinova, D., Ribarova, F. and Atanassova, M. (2005). Total phenolics and total flavonoids in Bulgarian fruits and vegetables. Journal of the university of chemical Technology and Metallurgy, 40: 255-260.

Minaxi, R., Vinayak, D., Tarak, P., and Rema, S. (2013). Effect of in bio-processing on antioxidant activity of selected cereals. Asian Journal of Plant Science and Research. $3(2): 66-72$.

Obilana, A.B. and Manyan, E. (2002). Millets. In:Pseudocereals and less common cereals:Grain properties and utilization potential (edited by BELTON, P. and TAYLOR, J.). Pp. 177-218. New York:Springer.

Oh, K.S. (1994). Changes in lipid components of Pollack during sundrying. Korean Journal of food Science and Technology. 26:123-126.

Onyango, C.A., Ochanda, S.O., Mwajaru, M.A., Ochieng J.K. and Mathooko, F.M. (2012). Development of instant breakfast cereals from optimized flour of pearl millet, red and white sorghum. Journal of applied biosciences, 51:3559-3566. 